Bull. Chem. Soc. Ethiop. 2021, 35(2), 425-434.

(C) 2021 Chemical Society of Ethiopia and The Authors

ISSN 1011-3924

DOI: https://dx.doi.org/10.4314/bcse.v35i2.15

Printed in Ethiopia

Online ISSN 1726-801X

\title{
KINETICS AND MECHANISTICS STEPS TO THE ELECTRON TRANSFER REACTION OF PEROXO-BRIDGED BINUCLEAR COBALT(III) COMPLEX OF SUCCINIMIDE BY GLYCINE IN AQUEOUS ACIDIC MEDIUM
}

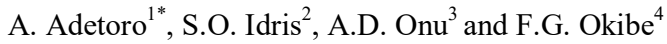 \\ ${ }^{1}$ Department of Chemistry, Nigerian Army University, Biu, Borno State, Nigeria \\ ${ }^{2}$ Department of Chemistry, Ahmadu Bello University, Zaria, Kaduna State, Nigeria \\ ${ }^{3}$ Department of Chemistry, Federal College of Education, Zaria, Kaduna State, Nigeria \\ ${ }^{4}$ Department of Chemistry, Federal University of Health Sciences, Otukpo, Benue State, \\ Nigeria
}

(Received March 1, 2021; Revised September 4, 2021; Accepted September 10, 2021)

\begin{abstract}
The kinetics and mechanistic steps to the electron transfer reaction of the peroxo-bridged binuclear cobalt(III) complex of succinimide $\left[(\mathrm{suc})(\mathrm{en})_{2} \mathrm{Co}\left(\mathrm{O}_{2}\right) \mathrm{Co}(\mathrm{en})_{2}(\mathrm{suc})^{2+}\right]$ hereafter called peroxo-bridged dicobalt(III) complex ' $\left[\mathrm{Co}\left(\mathrm{O}_{2}\right) \mathrm{Co}^{2+}\right]$ ' by glycine have been carried out spectrophotometrically at $\lambda=420 \mathrm{~nm}$ and $\mathrm{T}$ $=26 \pm 1{ }^{\circ} \mathrm{C},\left[\mathrm{H}^{+}\right]=1 \times 10^{-3} \mathrm{M}$ and $\left.\mathrm{u}_{+}=0.5 \mathrm{M} \mathrm{(NaCl}\right)$ in aqueous acidic medium. The reaction was found to be first order with respect to $\left[\mathrm{Co}\left(\mathrm{O}_{2}\right) \mathrm{Co}^{2+}\right]$ and $[(\mathrm{Gly}]$ and experimental data indicates a second-order overall. The reactions obeyed the general rate law: $\left.\left(\mathrm{d}\left[\mathrm{Co}\left(\mathrm{O}_{2}\right) \mathrm{Co}^{2+}\right] / \mathrm{dt}\right)=(\mathrm{a}+\mathrm{b})\left[\mathrm{H}^{+}\right]\right)\left[\mathrm{Co}\left(\mathrm{O}_{2}\right) \mathrm{Co}^{2+}\right][\mathrm{Gly}]$. Varying hydrogen ion concentration accelerated the reaction rate and shows first-order dependence while the reactions also affected by changes in the ionic strength of the reaction medium by giving a non-negative salt effect in the course of the reaction. Free radicals were not detected in the reactions. Spectroscopic investigation and Michaelis-Menten plots suggest the absence of intermediate complex formation. The experimental result obtained in this system is concluded in favor of the outer-sphere mechanism.
\end{abstract}

KEY WORDS: Cobalt(III) complex, Kinetic, Electron transfer, Spectroscopic, Mechanistic steps, MichaelisMenten, Glycine

\section{INTRODUCTION}

The inorganic mechanistic study is relevance across coordination chemistry, organometallic synthetic chemistry, and the biochemical role of metals. The interaction of oxygen with other atoms and the importance of this in the bridging to other atoms is a concern which investigators in the structural elucidation of chemical compounds have been dealing with in recent years [1]. Fremy was the first to report dicobalt(III) complexes in 1852 and later Werner established the preparation of a wide range of ammine and ethylenediamine complexes in 1910, with many bridging groups [1-2]. Many $\mathrm{Co}(\mathrm{III})$-dioxygen complexes are formed via the oxidative addition of oxygen atom $\left(\mathrm{O}_{2}\right)$ to the corresponding $\mathrm{Co}(\mathrm{II})$ precursors [3]. Two oxidation states of dicobalt complexes with $\mathrm{O}_{2}$ bridging ligands are known. These two types can be classified into (i) $\mathrm{O}_{2}^{-}$, 'superoxo' and (ii) $\mathrm{O}_{2}{ }^{2-}$, peroxo-bridged complexes, respectively [4-5].

The requisite quantity of $\mu$-peroxo-bis[aminebis(ethylenediamine)cobalt(III)]perchlorate dehydrate prepared by the solution route method has been reported [6]. Characterization of the complex was carried out by FT-IR and electronic spectroscopy techniques.

Literature has shown amino acid oxidation by $\mathrm{N}$-bromoacetamide in aqueous acidic medium where carbonyl compounds were reported as the products obtained from the reaction [6-7]. The reaction shows first-order in oxidant and amino acid, respectively.

Kinetic of interaction between amino acids such as glycine, DL-alanine and DLphenylalanine and cis-bis(malonate)diaquochromate(III) has been established in literature spectrophotometrically as a function of the amino acids [8]. The effect of $\mathrm{pH}$, temperature and

*Corresponding author. E-mail: lamedaplc@yahoo.com

This work is licensed under the Creative Commons Attribution 4.0 International License 
substrate is also studied and the substrate exists predominately as the diaquospecies and amino acids as the zwitterions at the experimental condition.

Iron(III)-1,10-phenanthroline complex with glycine kinetics and mechanism data studied in the presence of aqueous perchloric acid medium showed unity order to iron(III) and glycine, respectively [9]. The report indicates that increased concentration of phenanthroline increases the reaction, while an increase in $\mathrm{H}^{+}$concentration decreases the rate of the reaction.

Report of the oxidation of glycine by permanganate ion in aqueous phosphate buffers auto catalyzed by the soluble form of colloidal manganese dioxide as a reaction product has been established $[9,10]$. Both the catalytic and non-catalytic reaction pathways of permanganate were first order and glycine concentration respectively, however, the catalytic pathway had a kinetic order of unity for the autocatalytic agent and a non-integral order with glycine.

In spite of the interesting important biochemical features exhibited by glycine and peroxobridged dicobalt(III) complex, their kinetics studies have not been reported and this has led to the neglect in exploring their potential activity. This will rather be a step forward to gain mechanistic insight into its redox reaction as well in order to add to the already existing body of knowledge available on this complex.

\section{EXPERIMENTAL}

All the reagents used in this work were analytical grade. Peroxo-bridged dicobalt(III) complex was synthesized by adding weighed $2.91 \mathrm{~g} \mathrm{Co}\left(\mathrm{NO}_{3}\right)_{2} 6 \mathrm{H}_{2} \mathrm{O}$ to $20 \mathrm{~mL}$ water and $1.0 \mathrm{~g}$ succinimide was added. The reaction mixture was heated to $70{ }^{\circ} \mathrm{C}$ using heater magnetic stirrer and the $\mathrm{pH}$ was adjusted to 6 by adding $\mathrm{NaHCO}_{3}$ solution. Excess of ethylenediamine about 2 $\mathrm{mL}$ was added to the hot solution and stirrer at $70{ }^{\circ} \mathrm{C}$ for $30 \mathrm{~min}$ [11]. At the end of the reaction of the peroxo-bridged dicobalt(III) complexwith glycine, products formed was characterized by FT-IR to ascertain the kinds of end products in the course of the reaction as indicated by the spectral data presented in Table 1 .

Titration was carried out using spectrophotometric method to determining the stoichiometry of the reactants by keeping constant the $\left[\mathrm{Co}\left(\mathrm{O}_{2}\right) \mathrm{Co}^{2+}\right]$ while that of the [Glycine] were varied [12].

The rates of reactions were studied by observing the decrease in absorbance of $\left[\mathrm{Co}\left(\mathrm{O}_{2}\right) \mathrm{Co}^{2+}\right]$ at $420 \mathrm{~nm}$ and $\mathrm{T}=26 \pm 1{ }^{\circ} \mathrm{C}$ with a photoelectric colorimeter SM202 digital instrument with 3 digit LED, systronic brand and $50 \mathrm{~Hz}$ frequency, after having certified that none of the reactants had any significant absorbance at the said wavelength by running the spectrum of the products of the reaction. Pseudo-first order conditions were used to investigate kinetic measurement with [Glycine] in at least 10-folds excess over $\left[\mathrm{Co}\left(\mathrm{O}_{2}\right) \mathrm{Co}^{2+}\right]$ at constant temperature $\mathrm{T}=26 \pm 1{ }^{\circ} \mathrm{C}$, ionic strength as well as the hydrogen ion concentrations of the media [12].

Hydrogen ion concentrations $\left(\left[\mathrm{H}^{+}\right]\right)$on the rate of reaction was studied by varying concentrations of $\mathrm{HCl}$ from 1.0 to $1.4 \times 10^{-3} \mathrm{M}$ for $[\mathrm{Gly}] /\left[\mathrm{Co}\left(\mathrm{O}_{2}\right) \mathrm{Co}^{2+}\right]$ system, while the concentration of glycine, ionic strength, dicobalt(III) complex and temperature were kept constant [12].

Ionic strength in this system was determined by varying the concentration of inert electrolyte (sodium chloride) within the range $(0.1-1.3) \mathrm{M}$ while maintaining the concentrations of the oxidant, reductant, and hydrogen ion constant at stated reaction temperature [12, 13].

The added cations $\left(\mathrm{Ca}^{2+}, \mathrm{Mg}^{2+}\right)$ and anions $\left(\mathrm{HCOO}^{-}, \mathrm{CH}_{3} \mathrm{COO}^{-}\right)$on the reaction rates was studied by changing the concentrations of the ions from 30.0 to $130.0 \times 10^{-3} \mathrm{M}$ with all other conditions kept constant. The values of the added species-dependent rate constants in $[\mathrm{Gly}] /\left[\mathrm{Co}\left(\mathrm{O}_{2}\right) \mathrm{Co}^{2+}\right]$ system investigated were recorded.

Intermediate complex formation was examined by making the solutions of the reactant species mixed and their spectral recorded two minutes after the initiation of the reaction, over a range of wavelength (380-660 nm). Also, the Michaelis-Menten least-square plots of $1 / \mathrm{k}_{1}$ versus $1 /[\mathrm{Gly}]$ was plotted to find out whether there will be positive or zero or negligible intercept in 
the plots. This is to ascertain the absence or presence of intermediates complex formation during the course of the electron transfer.

\section{RESULTS AND DISCUSSION}

The results of the type of products formed as a result of formation of new bands after the reactions in the system analyzed using FT-IR are shown in Table 1.

Table 1. FT-IR Result of bands formation in $\left[\mathrm{Co}\left(\mathrm{O}_{2}\right) \mathrm{Co}^{2+}\right]-[\mathrm{Gly}]$.

\begin{tabular}{|l|l|l|l|l|}
\hline$\left[\mathrm{Co}\left(\mathrm{O}_{2}\right) \mathrm{Co}^{2+}\right]$ & Gly & $\begin{array}{l}\text { Reaction } \\
\text { mixture }\end{array}$ & Mode & Inference \\
\hline & 408.92 & 402.17 & $v(\mathrm{Co}-\mathrm{N})$ & $\begin{array}{l}\text { Coordination of N atoms of amino and carbonyl } \\
\text { groups from Gly to Co }\end{array}$ \\
\hline & & 440.75 & $v(\mathrm{Co}-\mathrm{N})$ & $\begin{array}{l}\text { Coordination of N atoms of amino and carbonyl } \\
\text { groups from Gly to Co }\end{array}$ \\
\hline 1354.07 & 1336.71 & 1336.71 & $v s .\left(\mathrm{COO}^{-}\right)$ & $\begin{array}{l}\text { Involvement of coordination of carboxylate } \\
\text { groups }\end{array}$ \\
\hline & & 1539.25 & $v(\mathrm{C}=\mathrm{O})$ & Carbonyl groups \\
\hline & 1610.61 & 1646.3 & $\mathrm{C}=\mathrm{N}$ & Nitrogen atoms from Gly \\
\hline 2960.83 & 2181.56 & 2083.19 & $v\left(\mathrm{NH}^{3+}\right)$ str & Coordinated thiocyanato group from Gly \\
\hline 3432.44 & 2899.11 & 2945.4 & $\mathrm{~N}-\mathrm{H}$ & Vibration from Gly \\
\hline
\end{tabular}

Peroxo-bridged dicobalt(III) complex $=\left[\mathrm{Co}\left(\mathrm{O}_{2}\right) \mathrm{Co}^{2+}\right], \mathrm{v}$ is stretching vibration mode as represents asymmetric vibration; $v s$. represents symmetric vibrations. All vibrations are in $\mathrm{cm}^{-1}$.

Stoichiometric studies using the mole ratio method indicate that plots of $\mathrm{A}_{\infty}$ (absorbance at infinity) versus mole ratio $\left([\mathrm{Gly}] /\left[\mathrm{Co}\left(\mathrm{O}_{2}\right) \mathrm{Co}^{2+}\right]\right.$ ) had sharp breaks at ratio $1: 1$ (Figure 1), an indication that one mole of $\left[\mathrm{Co}\left(\mathrm{O}_{2}\right) \mathrm{Co}^{2+}\right]$ is being consumed by a mole of glycine investigated as presented in Equation 1

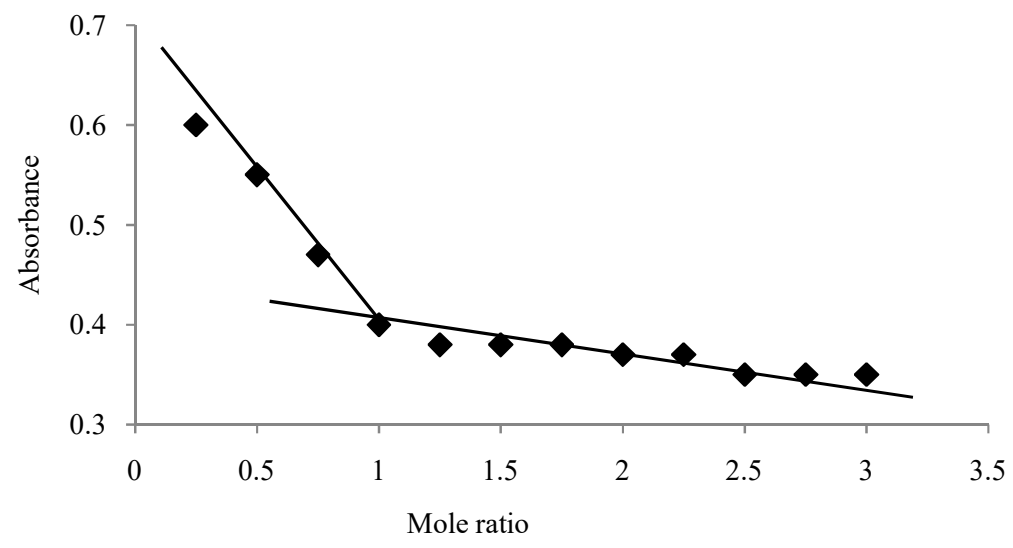

Figure 1. Plot of absorbance versus mole ratio for the redox reaction of $\left[\mathrm{Co}\left(\mathrm{O}_{2}\right) \mathrm{Co}^{2+}\right]$ with glycine at $\left[\mathrm{H}^{+}\right]=1 \times 10^{-3} \mathrm{M}, \mu=0.5 \mathrm{M},[\mathrm{Gly}]=(7.0-49.0) \times 10^{-5} \mathrm{M}, \mathrm{T}=26 \pm 1{ }^{\circ} \mathrm{C}$, $\lambda_{\max }=420 \mathrm{~nm},\left[\mathrm{Co}\left(\mathrm{O}_{2}\right) \mathrm{Co}^{2+}\right]=1.4 \times 10^{-4} \mathrm{M}$.

$\left[\mathrm{Co}\left(\mathrm{O}_{2}\right) \mathrm{Co}^{2+}\right]+[\mathrm{Gly}] \rightarrow \mathrm{Co}^{2+}+\mathrm{COO}^{-}+$other products 
This is similar to the report of the reaction of the peroxo bridged binuclear cobalt(III) with Lcysteine [14-16].

The $90 \%$ linearity in the plots of $\log \left(\mathrm{A}_{\mathrm{t}}-\mathrm{A}_{\infty}\right)$ against time (Figure 2) using least square means shows that the order for $\left[\mathrm{Co}\left(\mathrm{O}_{2}\right) \mathrm{Co}^{2+}\right]$ is unity and this is in agreement with already reported in literature [17]. Rate constants, $\mathrm{k}_{1}$, obtained from the slopes of these plots are presented in Table 2. Plots of $\log \mathrm{k}_{1}$ versus Log [Gly] (Figure 3) give a straight line with a slope of 0.98 , indicate unity order dependence on glycine concentration and second-order overall (Equation 3).

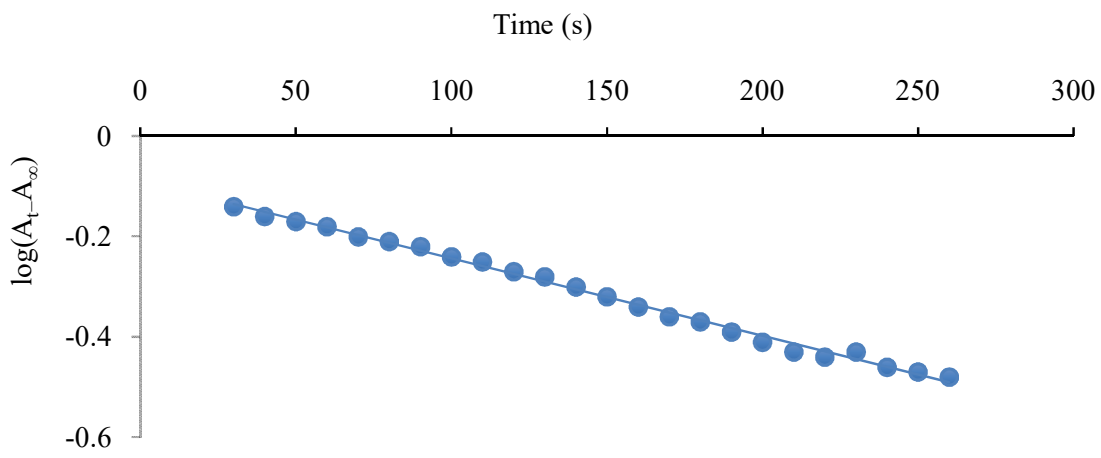

Figure 2. Representative pseudo-first order plot in $\left[\mathrm{Co}\left(\mathrm{O}_{2}\right) \mathrm{Co}^{2+}\right] /[\mathrm{Gly}]$ system at $[\mathrm{H}+]=1.0 \mathrm{x}$ $10^{-2} \mathrm{M},\left[\mathrm{Co}\left(\mathrm{O}_{2}\right) \mathrm{Co}^{2+}\right]=1.4 \times 10^{-4} \mathrm{M},[\mathrm{Gly}]=19.6 \times 10^{-3} \mathrm{M}, \lambda_{\max }=420 \mathrm{~nm}, \mathrm{~T}=26 \pm 1$ ${ }^{\circ} \mathrm{C}, \mathrm{u}_{\mathrm{b}}=0.50 \mathrm{M}(\mathrm{NaCl})$.

The second-order rate constants, $\mathrm{k}_{2}$, was obtained from Equation 2.

$\mathrm{k}_{2}=\frac{k_{1}}{[\text { Glycine }]}$

This was found to be fairly consistent as indicated in Table 2 and similar to the report of the established literature [18].

$\left(-\mathrm{d}\left[\mathrm{Co}\left(\mathrm{O}_{2}\right) \mathrm{Co}^{2+}\right] / \mathrm{dt}\right)=\mathrm{k}_{2}\left[\mathrm{Co}\left(\mathrm{O}_{2}\right) \mathrm{Co}^{2+}\right] /[\mathrm{Gly}]$

The results of the order with glycine concentration (Figure 3) is in agreement with already reported hexacyanoferrate(III) (abbreviated as HCF) ions oxidation by some amino acids in the presence of $\operatorname{Ir}(\mathrm{III})$ catalyst in aqueous alkaline medium at a constant ionic strength of $0.5 \mathrm{M}$ and temperature $35^{\circ} \mathrm{C}$ [19]. In the oxidation of glycine by permanganate ions in aqueous phosphate buffers first order to glycine has also been reported [20].

The acid dependence rate constants presented in Table 2 suggest that the reaction rate increases as the $\left[\mathrm{H}^{+}\right]$increased. The plots of $\log \mathrm{k}_{1}$ versus $\log \left[\mathrm{H}^{+}\right]$for the system gave a slope of 0.78 (Figure 4), showing that the rates are first-order acid-dependent in the reaction.

The dependence of the second-order rate constants on the $\left[\mathrm{H}^{+}\right]$for the reactions as presented in Table 2, with the least square plots of $\mathrm{k}_{2}$ versus $\left[\mathrm{H}^{+}\right]^{\mathrm{n}}$. The plot is linear with a positive intercept as shown in Figure 5. The relationship between $\mathrm{k}_{2}$ and $\left[\mathrm{H}^{+}\right]^{\mathrm{n}}$ can be represented by Equation 4.

$\mathrm{k}_{2}=\mathrm{a}+\mathrm{b}\left[\mathrm{H}^{+}\right]$

The nature of acid dependence depicts that there are two terms in the rate equations: one being direct dependence on hydrogen ion concentration and the other independence of hydrogen ion concentration. 
Table 2. First and second order rate constant for the redox reaction of glysine by $\left[\mathrm{Co}\left(\mathrm{O}_{2}\right) \mathrm{Co}^{2+}\right]$ in aqueous $\mathrm{HCl}$ medium at $\mathrm{T}=26 \pm 1^{\circ} \mathrm{C}, \mathrm{u}_{\mathrm{t}}=0.50 \mathrm{M}(\mathrm{NaCl}),\left[\mathrm{Co}\left(\mathrm{O}_{2}\right) \mathrm{Co}^{2+}\right]=1.4 \times 10^{-4} \mathrm{M}, \lambda_{\max }=420 \mathrm{~nm}$.

\begin{tabular}{|l|l|l|l|l|}
\hline $10^{3}[$ Glysine $]$ & $10^{3}\left[\mathrm{H}^{+}\right]$ & $10[\mu]$ & $10^{3} \mathrm{k}_{1}\left(\mathrm{~s}^{-1}\right)$ & $\mathrm{k}_{2}\left(\mathrm{M}^{-1} \mathrm{~s}^{-1}\right)$ \\
2.8 & 1.0 & 5.0 & 6.10 & 2.18 \\
5.6 & 1.0 & 5.0 & 12.15 & 2.17 \\
8.4 & 1.0 & 5.0 & 18.39 & 2.19 \\
11.2 & 1.0 & 5.0 & 24.08 & 2.15 \\
14.0 & 1.0 & 5.0 & 30.52 & 2.18 \\
16.8 & 1.0 & 5.0 & 36.28 & 2.16 \\
19.6 & 1.0 & 5.0 & 42.14 & 2.15 \\
16.8 & 0.2 & 5.0 & 14.11 & 0.84 \\
16.8 & 0.4 & 5.0 & 21.33 & 1.27 \\
16.8 & 0.6 & 5.0 & 26.20 & 1.56 \\
16.8 & 0.8 & 5.0 & 32.25 & 1.92 \\
16.8 & 1.0 & 5.0 & 36.28 & 2.16 \\
16.8 & 1.2 & 5.0 & 50.06 & 2.98 \\
16.8 & 1.4 & 5.0 & 57.45 & 3.42 \\
16.8 & 1.0 & 1.0 & 17.30 & 1.03 \\
16.8 & 1.0 & 3.0 & 23.01 & 1.37 \\
16.8 & 1.0 & 5.0 & 36.28 & 2.16 \\
16.8 & 1.0 & 7.0 & 37.46 & 2.23 \\
16.8 & 1.0 & 9.0 & 39.81 & 2.37 \\
16.8 & 1.0 & 1.1 & 48.55 & 2.89 \\
16.8 & 1.0 & 1.3 & 52.58 & 3.13 \\
\hline
\end{tabular}

$\log [\mathrm{Gly}]$

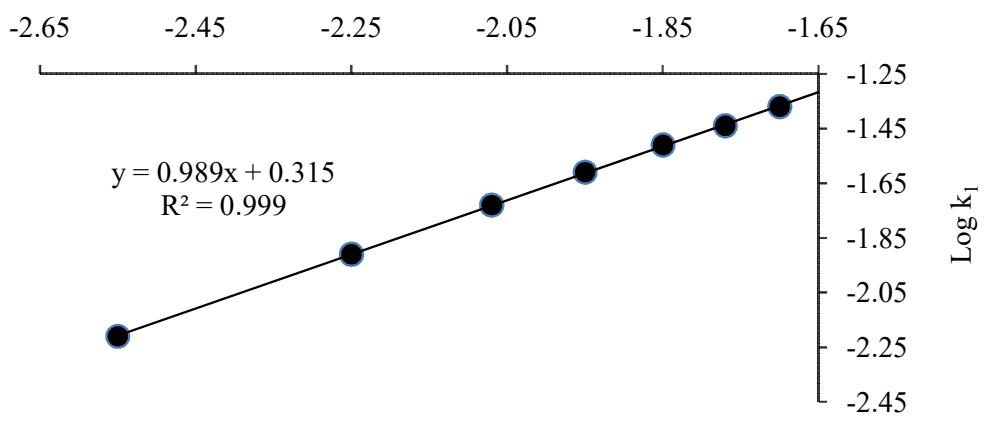

Figure 3. $\log \mathrm{k}_{1}$ against $\log [\mathrm{Gly}]$ in the reaction of $\left[\mathrm{Co}\left(\mathrm{O}_{2}\right) \mathrm{Co}^{2+}\right]$ and glycine at $\left[\mathrm{H}^{+}\right]=1.0 \times 10^{-}$

${ }^{3} \mathrm{M}, \mu=0.5 \mathrm{M},[\mathrm{Gly}]=(2.8-19.6) \times 10^{-3} \mathrm{M}, \mathrm{T}=26 \pm 1{ }^{\circ} \mathrm{C}, \lambda=420 \mathrm{~nm},\left[\mathrm{Co}\left(\mathrm{O}_{2}\right) \mathrm{Co}^{2+}\right]$ $=1.4 \times 10^{-4} \mathrm{M}$. 


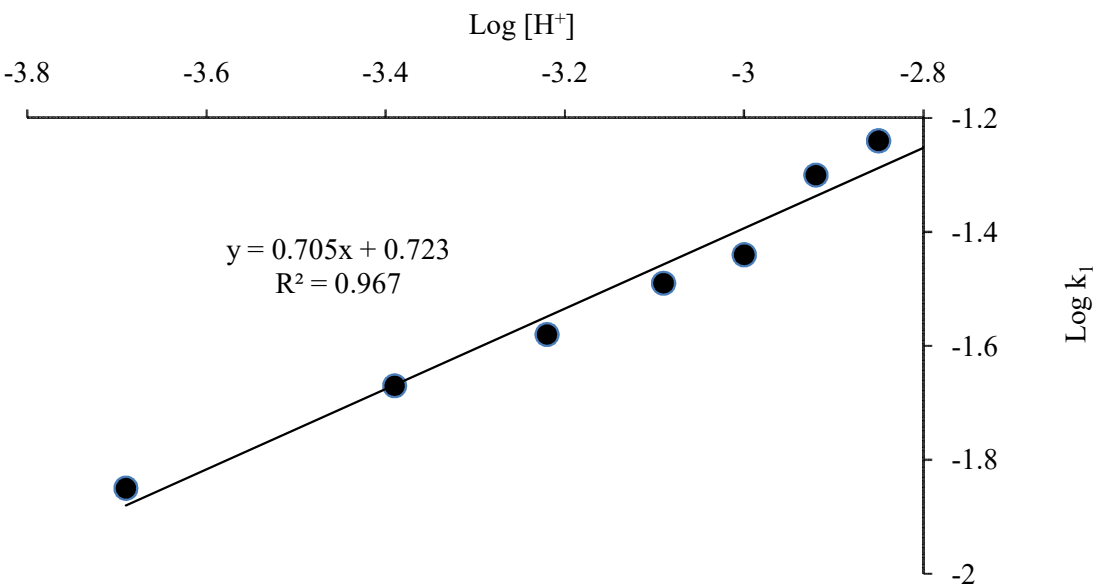

Figure 4. $\log \mathrm{k}_{1}$ against $\log \left[\mathrm{H}^{+}\right]$for the reaction of $\left[\mathrm{Co}\left(\mathrm{O}_{2}\right) \mathrm{Co}^{2+}\right]$ and glycine at $\left[\mathrm{H}^{+}\right]=(0.2-$ 1.4) $\times 10^{-3} \mathrm{M}, \mu=0.5 \mathrm{M},[\mathrm{Gly}]=16.8 \times 10^{-3} \mathrm{M}, \mathrm{T}=26.0 \pm 1{ }^{\circ} \mathrm{C}$ and $\lambda_{\max }=420 \mathrm{~nm}$, $\left[\mathrm{Co}\left(\mathrm{O}_{2}\right) \mathrm{Co}^{2+}\right]=1.4 \times 10^{-4} \mathrm{M}$.

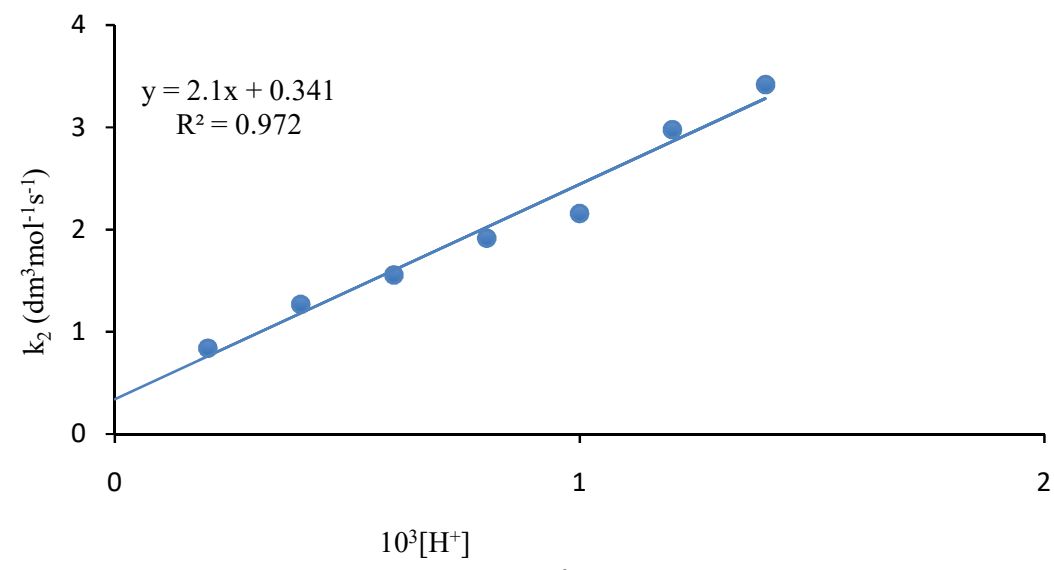

Figure 5. $\mathrm{k}_{2}$ against $\left[\mathrm{H}^{+}\right]$for the reaction of $\left[\mathrm{Co}\left(\mathrm{O}_{2}\right) \mathrm{Co}^{2+}\right]$ and glycine at $\left[\mathrm{H}^{+}\right]=(0.2-1.4) \times 10^{-3}$ $\mathrm{M},\left[\mathrm{Co}\left(\mathrm{O}_{2}\right) \mathrm{Co}^{2+}\right]=1.4 \times 10^{-4} \mathrm{M}, \mu=0.5 \mathrm{~mol} \mathrm{dm}^{-3},[\mathrm{Gly}]=16.8 \times 10^{-3} \mathrm{M}, \mathrm{T}=26.0 \pm$ $1{ }^{\circ} \mathrm{C}$ and $\lambda_{\max }=420 \mathrm{~nm}$.

The generalized rate equation for the reactions can therefore be presented as Equation 5 .

$\left(-\mathrm{d}\left[\mathrm{Co}\left(\mathrm{O}_{2}\right) \mathrm{Co}^{2+}\right] / \mathrm{dt}\right)=(\mathrm{a}+\mathrm{b})\left[\mathrm{H}^{+}\right]\left[\mathrm{Co}\left(\mathrm{O}_{2}\right) \mathrm{Co}^{2+}\right][\mathrm{Gly}]$

The effect of changes in ionic strength $(\mu)$ on the rate of reaction was investigated in the range $(1.0-1.3) \times 10^{-1} \mathrm{M}$ sodium chloride for the glycine and the $\left[\mathrm{Co}\left(\mathrm{O}_{2}\right) \mathrm{Co}^{2+}\right]$ while others reactant were kept constant as shown in Table 2 . The rate constant $\left(\mathrm{k}_{2}\right)$ was found to increase with an increase in the ionic strength $(\mu)$ in this system that is as $[\mu]$ is increases $k_{2}$ also increases. Plots of $\log k_{2}$ versus $\sqrt{\mu}$ for this system is linear, with a positive slope (Figure 6). This positive slope shows that same charges occur at the rate-determining step in the course of reaction as postulated by Bronsted-Debye [21]. 
The results of the effect of ions indicate that the presence of $\mathrm{Ca}^{2+}, \mathrm{Mg}^{2+}, \mathrm{HCOO}^{-}$and $\mathrm{CH}_{3} \mathrm{COO}^{-}$as shown in Table 3 and 4 , altered the rate of $[\mathrm{Gly}] /\left[\mathrm{Co}\left(\mathrm{O}_{2}\right) \mathrm{Co}^{2+}\right]$ system investigated. Enhancement of rate constants or the increase in the rate constants by the added anions and inhibition or decrease in rate constants by cations is suggestive of the fact that since the charges at the activated complex is positive. The addition of cations would lead to repulsion thereby inhibiting the rates, while the added anions would lead to attraction and consequent increase in the rate constant.

The results of the spectroscopic studies showed no shift from the characteristic absorption maxima for the mixtures, evidence of the outer-sphere mechanism. The Michaelis-Menten leastsquare plots of $1 / \mathrm{k}_{1}$ versus $1 /[\mathrm{Gly}]$ for the system is linear with zero intercepts (Figure 7) [22]. This indicates the probable absence of intermediates complex formation with an appreciable equilibrium constant during the course of the electron transfer.

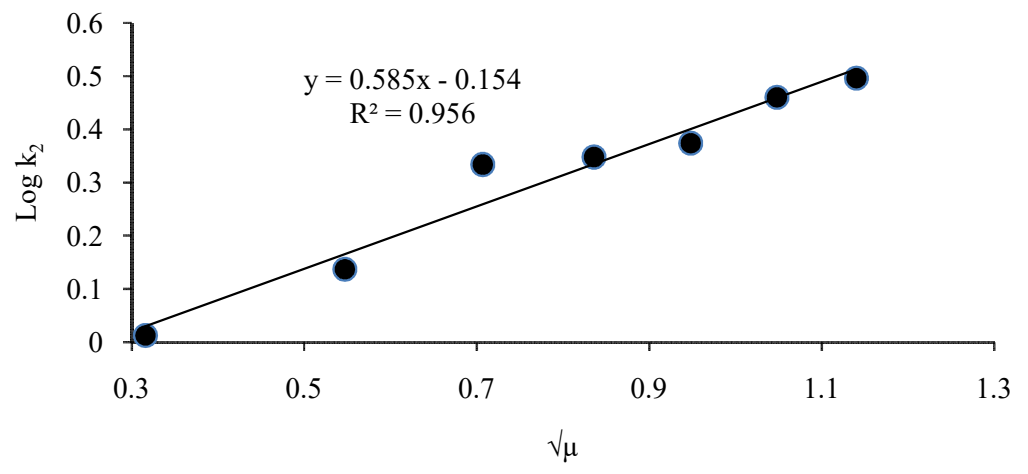

Figure 6. $\log \mathrm{k}_{2}$ against $\sqrt{\mu}$ for the reaction of $\left[\mathrm{Co}\left(\mathrm{O}_{2}\right) \mathrm{Co}^{2+}\right]$ and glycine at $\left[\mathrm{H}^{+}\right]=1.0 \times 10^{-3} \mathrm{M}$, $\left[\mathrm{Co}\left(\mathrm{O}_{2}\right) \mathrm{Co}^{2+}\right]=1.4 \times 10^{-4} \mathrm{M}, \mu=(1.0-1.3) \times 10^{-1} \mathrm{M},[\mathrm{Gly}]=19.6 \times 10^{-3} \mathrm{M}, \mathrm{T}=26.0 \pm$ $1^{\circ} \mathrm{C}$ and $\lambda_{\max }=420 \mathrm{~nm}$

Table 3. Rate constants by cations between the $\left[\mathrm{Co}\left(\mathrm{O}_{2}\right) \mathrm{Co}^{2+}\right]$-Glycine system at $\mu=0.5 \mathrm{M}$ (sodium chloride) $, \mathrm{T}=26 \pm 1^{\circ} \mathrm{C},[\mathrm{Gly}]=16.8 \times 10^{-3} \mathrm{M}, \quad\left[\mathrm{Co}\left(\mathrm{O}_{2}\right) \mathrm{Co}^{2+}\right]=1.4 \times 10^{-4} \mathrm{M}, \lambda_{\max }=420 \mathrm{~nm}$ and $\left[\mathrm{H}^{+}\right]=1.0 \times 10^{-3} \mathrm{M}$

\begin{tabular}{|l|l|l|}
\hline $10^{2}\left[\mathrm{Ca}^{2+}\right]$ & $10^{3} \mathrm{k}_{1}\left(\mathrm{~s}^{-1}\right)$ & $\mathrm{k}_{2}\left(\mathrm{M}^{-1} \mathrm{~s}^{-1}\right)$ \\
0.0 & 36.28 & \\
3.0 & 34.10 & 2.16 \\
5.0 & 32.76 & 2.03 \\
7.0 & 28.05 & 1.95 \\
9.0 & 23.18 & 1.67 \\
11.0 & 21.67 & 1.38 \\
13.0 & 18.64 & 1.29 \\
& & 1.11 \\
$10^{2}\left[\mathrm{Mg}^{2+}\right]$ & & \\
0.0 & 36.28 & 2.16 \\
3.0 & 32.08 & 1.91 \\
5.0 & 29.90 & 1.78 \\
7.0 & 26.20 & 1.56 \\
9.0 & 27.04 & 1.61 \\
11.0 & 24.02 & 1.43 \\
13.0 & 20.32 & 1.21 \\
\hline
\end{tabular}

Bull. Chem. Soc. Ethiop. 2021, 35(2) 
Table 4. Rate constants by anions between the $\left[\mathrm{Co}\left(\mathrm{O}_{2}\right) \mathrm{Co}^{2+}\right]$ - glycine system at $\mu=0.5 \mathrm{M}$ (sodium chloride) $, \mathrm{T}=26 \pm 1{ }^{\circ} \mathrm{C},[\mathrm{Gly}]=16.8 \times 10^{-3} \mathrm{M}, \quad\left[\mathrm{Co}\left(\mathrm{O}_{2}\right) \mathrm{Co}^{2+}\right]=1.4 \times 10^{-4} \mathrm{M}, \lambda_{\max }=420 \mathrm{~nm}$ and $\left[\mathrm{H}^{+}\right]=1.0 \times 10^{-3} \mathrm{M}$.

\begin{tabular}{|l|l|l|}
\hline $10^{2}\left[\mathrm{HCOO}^{-}\right]$ & $10^{3} \mathrm{k}_{1}\left(\mathrm{~s}^{-1}\right)$ & $\mathrm{k}_{2}\left(\mathrm{M}^{-1} \mathrm{~s}^{-1}\right)$ \\
0.0 & 36.28 & \\
3.0 & 38.30 & 2.16 \\
5.0 & 39.64 & 2.28 \\
7.0 & 41.32 & 2.36 \\
9.0 & 44.18 & 2.46 \\
11.0 & 46.36 & 2.63 \\
13.0 & 47.71 & 2.76 \\
& & 2.84 \\
$10^{2}\left[\mathrm{CH}_{3} \mathrm{COO}^{-}\right]$ & & \\
0.0 & 36.28 & 2.16 \\
3.0 & 39.14 & 2.33 \\
5.0 & 42.00 & 2.50 \\
7.0 & 46.36 & 2.76 \\
9.0 & 49.89 & 2.97 \\
11.0 & 51.74 & 3.08 \\
13.0 & 52.92 & 3.15 \\
\hline
\end{tabular}

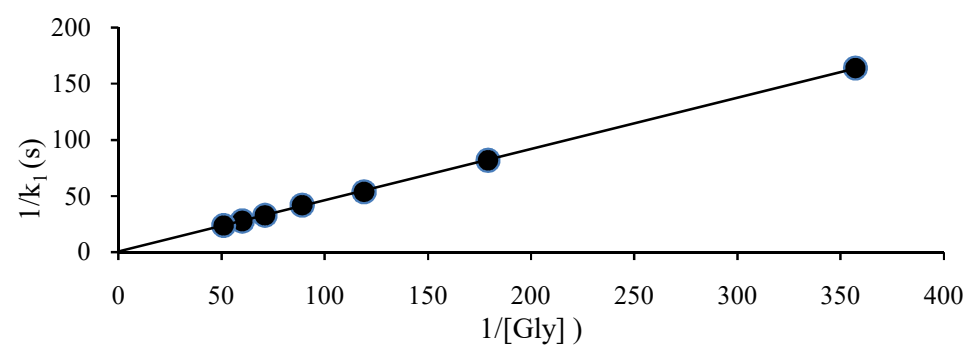

Figure 7. Plot of $1 / \mathrm{k}_{1}(\mathrm{~s})$ versus $1 /\left[\right.$ Glycine] for the reaction of $\left[\mathrm{Co}\left(\mathrm{O}_{2}\right) \mathrm{Co}^{2+}\right]$ and glycine at $\left[\mathrm{H}^{+}\right]$ $=1.0 \times 10^{-3} \mathrm{M},\left[\mathrm{Co}\left(\mathrm{O}_{2}\right) \mathrm{Co}^{2+}\right]=1.4 \times 10^{-4} \mathrm{M}, \mu=0.5 \mathrm{M},[\mathrm{Gly}]=(2.8-19.6) \times 10^{-3} \mathrm{M}$, $\mathrm{T}=26 \pm 1{ }^{\circ} \mathrm{C}$ and $\lambda=420 \mathrm{~nm}$.

Based on the results obtained in this study, plausible mechanism is proposed as:

$$
\begin{array}{lr}
{[\mathrm{Gly}]+\left[\mathrm{H}^{+}\right] \rightleftarrows \mathrm{HGly}^{+}} & \mathrm{K}_{1}(6) \\
{\left[\mathrm{Co}\left(\mathrm{O}_{2}\right) \mathrm{Co}^{2+}\right]+\left[\mathrm{HGly}^{+}\right] \rightleftarrows\left[\mathrm{Co}\left(\mathrm{O}_{2}\right) \mathrm{Co}^{2+}, \mathrm{HGly}\right]^{3+}} & \mathrm{K}_{2}(7) \\
{\left[\mathrm{Co}\left(\mathrm{O}_{2}\right) \mathrm{Co}^{2+}, \mathrm{HGly}\right]^{3+} \rightarrow \text { Products }} & \mathrm{k}_{3}(8) \\
{\left[\mathrm{Co}\left(\mathrm{O}_{2}\right) \mathrm{Co}^{2+}\right]+[\mathrm{Gly}] \rightleftarrows\left[\mathrm{Co}\left(\mathrm{O}_{2}\right) \mathrm{Co}^{2+}, \mathrm{Gly}\right]} & \mathrm{K}_{4}(9) \\
{\left[\mathrm{Co}\left(\mathrm{O}_{2}\right) \mathrm{Co}^{2+}, \mathrm{Gly}\right] \rightarrow \text { Products }} & \mathrm{k}_{5}(10) \\
\text { Rate }=k_{3}\left[\mathrm{Co}\left(\mathrm{O}_{2}\right) \mathrm{Co}^{2+}, \mathrm{HGly}^{3+}+\mathrm{k}_{5}\left[\mathrm{Co}\left(\mathrm{O}_{2}\right) \mathrm{Co}^{2+}, \mathrm{Gly}\right]\right. &
\end{array}
$$

From equaion 8 and 10 
$\left[\mathrm{Co}\left(\mathrm{O}_{2}\right) \mathrm{Co}^{2+}, \mathrm{HGly}\right]^{3+}=\mathrm{K}_{2}\left[\mathrm{Co}\left(\mathrm{O}_{2}\right) \mathrm{Co}^{2+}\right]\left[\mathrm{HGly}^{+}\right]$

$\left[\mathrm{Co}\left(\mathrm{O}_{2}\right) \mathrm{Co}^{2+}, \mathrm{Gly}\right]=\mathrm{K}_{4}\left[\mathrm{Co}\left(\mathrm{O}_{2}\right) \mathrm{Co}^{2+}\right][\mathrm{Gly}]$

Substituting equation 12 and 13 into equation 11 gives

Rate $=K_{2} k_{3}\left[\mathrm{Co}\left(\mathrm{O}_{2}\right) \mathrm{Co}^{2+}\right][\mathrm{HGly}]+\mathrm{K}_{4} k_{5}\left[\mathrm{Co}\left(\mathrm{O}_{2}\right) \mathrm{Co}^{2+}\right][\mathrm{Gly}]$

From equation 6

$[H G l y+]=K_{1}[G l y][H+]$

Substituting equation 15 into equation 14 gives

Rate $=K_{1} K_{2} k_{3}\left[\mathrm{Co}\left(\mathrm{O}_{2}\right) \mathrm{Co}^{2+}\right][G l y]\left[\mathrm{H}^{+}\right]+K_{4} k_{5}\left[\mathrm{Co}\left(\mathrm{O}_{2}\right) \mathrm{Co}^{2+}\right][\mathrm{Gly}]$

where $[\mathrm{Gly}]=$ Glycine.

The equation 16 is in agreement with equation 5.

\section{CONCLUSION}

The kinetics and mechanistic steps to the electron transfer reaction of peroxo-bridged binuclear cobalt(III) complex of succinimide have been studied in aqueous acidic media spectrophotometrically at $\lambda=420 \mathrm{~nm}$. The reaction was found to be first order with both the $\left[\mathrm{Co}\left(\mathrm{O}_{2}\right) \mathrm{Co}^{2+}\right]$ and [Glycine] and second-order overall. A positive Bronsted-Debye salt effect was found in the course of the reaction. Michealis-Menten plots with zero intercept showed no evidence of intermediate complex formation and the spectroscopic test indicates no shift in the wavelength absorption in the course of the reaction. Experimental data obtained in this study is in favor of outer-sphere plausible mechanistic pathways.

\section{ACKNOWLEDGEMENT}

The authors acknowledged the effort of late Prof J.F Iyun of the Department of Chemistry, Ahmadu Bello University, Zaria, Nigeria for providing an opportunity to broaden our knowledge in the area of inorganic reaction mechanisms.

\section{REFERENCES}

1. Olajire, A.A.; Olajide, A.J. Kinetic study of decolorization of methylene blue with sodium sulphite in aqueous media. Influence of transition metal ions. J. Phys. Chem. Biophys. 2014, 4, $2-7$.

2. Davies, G.; Watkins. K.O. Kinetics of some oxidation-reduction reactions involving cobalt(III) in aqueous perchloric acid. $J$ Phys Chem. 1970, 74, 3388-3390.

3. Hikichi, S.; Akita, M.; Moro-oka, Y. New aspects of the cobalt-dioxygen complex chemistry opened by hydrotris(pyrazoly)borate ligands $\left(\mathrm{Tp}^{\mathrm{R}}\right)$ : Unique properties of $\mathrm{Tp}^{\mathrm{R}} \mathrm{Co}$ dioxygen complexes. Coord. Chem. Rev. 2000, 198, 61-87.

4. Ryan, M.; Artur, S.; Fransis, F.S.C.; Olof, E.; Photodissociation of a ( $\mu$-peroxo)( $\mu$ hydroxo)bis[bis(bipyridyl)-cobalt(III)] complex: A tool to study fast biological reactions involving $\mathrm{O}_{2 .}$. Procnatacad. Sci. 1995, 92, 8105-8109. 
5. Solomon, M.B.; Rawal, A.; Hook, J.M.; Cohen, S.M.; Kubiak, C.P.; Jollife, K.A. Electro active Co(III) Salen metal complexes and the electrophoresis deposition of their porous organic polymers onto glassy carbon. RSC Adv. 2018, 8, 24128-24142.

6. Mahadeveppa, D.S.; Rangappa, K.S.; Gowda, N.M.M. Kinetics and mechanism of oxidation of L-threonine in acid media by sodium N-chloro- $p$-toluene sulfonamide. J. Phys. Chem. 1982, 85, 3651-3659.

7. Malharrao, R.T.; Gavisiddappa, S.G. Kinetics and mechanism of oxidation of glycine and alanine by oxone catalyzed with bromide ion. J. Braz. Chem. Soc. 2014, 25, 1545-1551.

8. Venkata, S.R.M; Ananta, V.R; Muralidhara, R.V. Kinetics of substitution of cisbis(malonato)diaquochromate(III) with glycine, DL-alanine, and DL-phenylalanine. Bull. Chem. Soc. Ethiop. 2009, 23, 197-204.

9. Partha, S.V.; Kalyan, K.A.; Krishna, K.K.; Vani, P. Kinetics and mechanism of oxidation of glycine by iron(III)-1,10-phenanthroline complex in perchloric acid medium. J. Chem. Sci. 2005, 117, 329-332.

10. Joaquin, F.P.; Fernando, M.; Enrique, B. Permanganate oxidation of glycine: Kinetics, catalytic effects and mechanism. Can. J. Chem. 1987, 65, 23-29.

11. Orphan, B. Synthesis and structural characterization of a novel peroxo bridged binuclear cobalt(III) complex of succinimide showing three varieties of hydrogen bonding interaction. J. Chem. Sci. 2009, 121, 267-273.

12. Adetoro, A.; Idris, S.O.; Onu, A.D.; Okibe, F.G.; Electon transfer reaction of glutamic acid and synthesized bis[bis(ethylenediamine)succinimidato-cobalt(III)]dinitratedihydrate in aqueous hydrochloric acidic acid. FUW Trends Sci. Technol. J. 2018, 3, 246-251.

13. Onu, A.D.; Iyun, J.F.; Idris, S.O. The kinetics of the reduction of tetraoxoiodate(VII) by $n$ (2-hydroxylethyyl)ethylenediaminetriacetocobaltate(II) ion in aqueous perchloric acid. Transit. Met. Chem. 2009, 34, 849-853.

14. Anweting, I. B.; Idris, S.O.; Onu, A.D. Kinetics and mechanism of oxidation of thiourea by tetrakis $(2,2$ '-bipyridine)- $\mu$-oxodiiron(III) complex in aqueous acidic media. FUW Trends Sci. Technol. J. 2017, 2, 856-860.

15. Iyun, J.F; Ayoko, G.A.; Mamman, S. Oxidation of N-(2-hydroxy ethyl) ethylenediamine triacetate by tris(polypyridy) iron(III) complex and the dodecaturigstocobaltate(III) ion. Transit. Met. Chem. 1993, 18, 475-477.

16. Ayoko, G.A.; Iyun, J.F.; El-Idris, I.F. Electron transfer at tetrahedral cobalt(II). Part IV: Kinetics of silver(I) catalyzed chlorate reduction. Transit. Met. Chem. 1993, 18, 275-278.

17. Adetoro, A.; Idris, S.O.; Onu, A.D.; Okibe, F.G. The kinetics of the oxidation of lysine by peroxo bridged binuclear cobalt(III) complex of succinimide in aqueous hydrochloric acidic medium. Ann. Sci. Technol. B 2017, 2, 37-43.

18. Ibrahim, I.; Idris, S.O.; Abdulkadir, I.; Onu, A.D. Redox reaction of $N, N^{\prime}$-phenylenebis-(salicylideneiminato)iron(III) with hypophosphorous acid in mixed aqueous medium. Transit. Met. Chem. 2020, 45, 211-216.

19. Anjali, G.; Ruchi, S. A kinetic and mechanistic study on the oxidation of arginine and lysine by hexacyanoferrate(III) catalyzed by iridium(III) in aqueous alkaline medium. $J$. Chem. Eng. Mater. Sci. 2012, 3, 1-6.

20 Hamza, S.A.; Iyun, J.F.; Idris, S.O. Kinetics and mechanism of the redox reaction of toluidine blue and nitrite ions in an aqueous acidic medium. Arch. Appl. Sci. Res. 2012, 4, $10-18$.

21. Atkins, P.W.; DePaula, J. Physical Chemistry, 7th ed. Oxford University Press: Oxford; 2002, p 962.

22. Kumar, J.; Suni, N. Analysis of autocatalytic reactions with Michealis-Menten kinetics in an isothermal continuous stirred tank reactor. Chem. Eng. Sci. 1997, 52, 3455-3462. 